\title{
Conservation Status of Marine Mammals in Cambodian Waters, Including Seven New Cetacean Records of Occurrence
}

\author{
Isabel L. Beasley ${ }^{1}$ and Peter J. A. Davidson ${ }^{2}$ \\ ${ }^{1}$ School of Tropical Environment Studies and Geography, James Cook University, Australia; \\ E-mail: isabel.beasley@jcu.edu.au \\ ${ }^{2}$ Bird Studies Canada, British Columbia Program, 5421 Robertson Road, Delta, BC, V4L 3N2, Canada
}

\begin{abstract}
The first dedicated, boat-based marine mammal surveys in Cambodian coastal waters were conducted over seven discrete survey periods, spanning February to September 2001. These surveys covered the majority of Cambodian coastal waters, in addition to the main offshore islands.

As a result of these surveys, ten marine mammal species have now been confirmed to occur in Cambodian waters. Six of these, the false killer whale, a long-beaked form of common dolphin, pantropical spotted dolphin, dwarf spinner dolphin, Indo-Pacific bottlenose dolphin, and IndoPacific humpback dolphin, constitute new country records for Cambodia. Additionally, a short-finned pilot whale was found live-stranded, constituting a further new country record. These initial results indicate that the current status of marine mammals in Cambodian waters is encouraging, both in terms of species diversity and abundance. Cambodian waters appear to support regionally, if not globally, significant populations of several of these species. The dugong is almost certainly the most highly threatened marine mammal in the region.

Studies to date have provided important baseline knowledge regarding the status, distribution, and important areas of occurrence for marine mammals in Cambodia. It is now essential that conservation and management strategies are developed and implemented. Public education and awareness and community-based management programs, as well as stricter laws, regulations, and adequate enforcement will be essential to conserving the remaining marine mammal populations and ensuring their survival in Cambodian coastal waters.
\end{abstract}

Key Words: cetacean, dugong, conservation, management, Cambodia, Indo-China

\section{Introduction}

The status of marine mammals in Southeast Asia has received very little focused study, although increased interest has been shown in recent years. Perrin et al. $(1995,1996,2005)$ provide the most comprehensive outline on the current status of marine mammal research and conservation in Southeast Asia.

There has been no previously documented research on marine mammals along the Cambodian coastline, and the status of marine mammals in the adjacent waters of Vietnam and Thailand remains poorly known and little studied. Initial records of cetaceans from Thai waters were noted in Bonhote (1903) and Suvatti (1950). The first detailed published accounts were undertaken by Pilleri \& Gihr (1974), which focused on the examination of marine mammal carcasses and skeletal material. Lekagul \& McNeely (1977) also provided detailed species accounts; however, some identifications therein were incorrect, despite being based on the authors' own photographs. A marine mammal research project was initiated in 1991 through the Phuket Marine Biological Centre in association with the Small Cetaceans in the Gulf of Thailand and Andaman Sea Project (Andersen \& Kinze, 1999; Chantrapornsyl et al., 1996, 1999). Interview and boat-based surveys, in addition to morphological and life history studies on coastal species, were undertaken in the Gulf of Thailand by Mahakunlayanakul (1996). Boat-based surveys were conducted in Songkhla Lake, southern Thailand, to assess the population of Irrawaddy dolphins (Orcaella brevirostris) (Beasley et al., 2002), and aerial surveys have been conducted on the Andaman Sea coast to assess dugong (Dugong dugon) distribution, abundance, and habitat use (Hines, 2005). To date, 20 species are confirmed from Thai waters. Although few dedicated surveys have been undertaken to assess abundance of marine mammals in Thai waters, indications are that coastal populations are small and many may be declining.

There have been few field studies of marine mammals along Vietnam's 3,260 km of coastline. A series of marine mammal surveys were undertaken in Vietnam that included riverine, coastal, 
and offshore waters (Smith et al., 1995, 1997). Although only two groups of Indo-Pacific humpback dolphins (Sousa chinensis) and one small unidentified whale were observed during these field surveys, a number of marine mammals were confirmed from "whale temples," with over 100 skulls observed at 18 whale temples throughout the country (Smith, 1996). Ho \& Nghi (1999) present a review on the status of marine mammals in Vietnamese waters. Interviews and direct observations have confirmed that the dugong inhabits the waters surrounding Con Dao National Park, Vietnam (Cox, 2000). This may be one of the last remaining populations of dugongs in Vietnamese waters; however, there is a strong possibility that dugongs are moving between this and other seagrass habitats in adjacent Cambodia. Resulting primarily from skeletal specimens, 17 marine mammal species have been documented from Vietnamese waters. The small number of sightings during boat-based surveys indicates that the abundance of cetaceans in Vietnamese waters may be alarmingly small.

The first known records of marine mammals along Cambodian coastal waters are noted by Lloze (1973) who describes records by Krempf (1924-1925) and Gruvel (1925) (both not viewed) who recorded (old nomenclature) Delphinus delphis, Steno (sotalia) sinensis Flower, Steno (sotalia) plumbea Dussumier, Steno rostratus, Neophocoena (Neomeris) phocoenoides, and Orcaella brevirostris. Additionally, an Irrawaddy dolphin skull was described by Monsieur $\mathrm{H}$. Argod (Lloze, 1973) as being found on one of the seven Pirate Isles, $6 \mathrm{~km}$ south of Kep (now in Vietnamese waters). The only previous information on marine mammals in Cambodia was outlined by Tana et al. (1995) and Perrin et al. (1996). During coastal surveys for coral and seagrass, Nelson (1999) observed finless porpoise (Neophocaena phoceanoides) and Irrawaddy dolphins. These are the only known confirmed records of cetaceans in the coastal waters of Cambodia. A Workshop on Marine Mammals and Sea Turtles of Cambodian, Thai and Vietnamese Waters was held at the Nha Trang Institute of Oceanography (8-13 February 1999) and is outlined in Andersen \& Kinze (2000). This paper mentions evidence for two new cetacean species records from Cambodia: the bottlenose dolphin and finless porpoise (citing the unpublished Andersen \& Kinze 1996 workshop report); these reports are regarded as unconfirmed, however, as details on the locations and specifics of the sightings were not provided, and the Andersen \& Kinze 1996 workshop report remains unpublished. Dugongs were reported to be abundant along parts of the Cambodian coast until approximately 1975 (Nelson, 1999). In
Koh Kong (near the Thailand border), dugongs were apparently most abundant near Prek Ksach. They were reportedly found in large groups, but their numbers declined substantially as a result of hunting, fishing, and loss of seagrass (Nay, 1998). Dugongs are now considered extirpated from the Koh Kong area (Nelson, 1999; Marsh et al., 2002).

Extensive research has recently been conducted by the first author on the Irrawaddy dolphin population that inhabits the lower Mekong River of southern Lao PDR, Cambodia, and Vietnam. This population now primarily inhabits a $190 \mathrm{~km}$ stretch of river from Khone Falls (just north of the Lao PDR/Cambodian border), south to Kratie Township, Cambodia. Based on a combination of line-transect and photo-identification survey methodologies from 2001 to 2005 , the total population was thought to only number between 127 to 161 individuals (95\% CL $=89$ to 289 ) as of April 2005 (Beasley, 2007). The Irrawaddy dolphin population inhabiting the Mekong River is not discussed further in this paper.

\section{Materials and Methods}

Study Area

Cambodia's coastline measures $435 \mathrm{~km}$ in length. The seaward boundary of the coastal zone has been delimited as the outer limit of the Exclusive Economic Zone (seemingly referring to Cambodian territorial waters) and covers a total area of $55,600 \mathrm{~km}^{2}$ (Nelson, 1999). The coastal zone is wholly encompassed within the Provinces of Koh Kong and Kampot, and the Municipalities of Kompong Som (Sihanoukville) and Kep (Nelson, 1999).

Despite its relatively shortlength, the Cambodian coastline supports quite a variety of habitats. The seas are generally shallow, seldom exceeding $60 \mathrm{~m}$ even in the most remote offshore waters. The seabed is generally of very gentle gradient, lacking any marked "shelfing" or other prominent underwater features. There are substantial areas of mangrove, most notably around Koh Kong Bay and the Peam Krasaop Wildlife Sanctuary immediately to the north (both in the northern coastal section of Koh Kong Province), around the western and northern shores of Kompong Som Bay (southern Koh Kong Province), in Ream National Park (Kompong Som Municipality), and between Kampot and Kep (southern Kampot Province). Sandy beaches are found along much of the country's coastline, particularly in Kompong Som Municipality, but also in Koh Kong and Kampot Provinces, and the numerous bays around offshore islands. There are at least 52 islands off the Cambodian mainland, many of which 
are uninhabited, varying in size from tiny rocky islets (e.g., Ilot Kusrovie) to large islands (e.g., Koh Kong and Koh Rong). Coral occurs around many islands. Although data on benthic species status, distribution, and species composition of these areas is scant at best, it appears that most, if not all, have suffered varying degrees of degradation.

Eight species of seagrass have been recorded from Cambodian waters (Ethirmannasingam, 1996), although further research needs to be conducted to confirm species identification. Extensive seagrass beds occur in the waters off Kampot and Kep, and indeed formerly around much of the country's coastline (e.g., Kompong Som Bay) as well as offshore. Smaller seagrass beds occur intermingled with corals around islands; however, seagrass beds have been heavily impacted by the activities of trawl and weighted bottom-net fisheries (Nelson, 1999).

\section{Survey Methods}

Boat-Based Surveys-Preliminary boat-based surveys to assess marine mammal distribution and abundance were undertaken throughout Cambodian coastal and offshore waters using local fishing boats (sizes ranged from small gillnet boats with a viewing platform $1 \mathrm{~m}$ above the water's surface to larger trawlers with a viewing platform $3 \mathrm{~m}$ above the water's surface). Linetransect surveys of offshore and inshore waters were undertaken using a converted logging barge (ca $14 \mathrm{~m}$ in length, providing a viewing platform at the bow of ca $3 \mathrm{~m}$ above the water's surface). The method used throughout the line-transect surveys was adapted from Aragones et al. (1997), using standardised distance sampling techniques designed for analysis following Buckland et al. (1993). One observer used the naked eye and one used a pair of Nikon $7 \mathrm{x}$ binoculars with an inbuilt compass. Observers were switched on a 30-min rotation schedule. The boat followed a set of predetermined survey lines, using a global positioning system (GPS). Speed was kept constant at 9 to $11 \mathrm{~km} / \mathrm{h}$. Environmental parameters (Beaufort sea state, depth, and visibility) were taken every 30 min throughout the surveys. Additionally, salinity (when a refractometer could be obtained) and depth were measured at the point of each marine mammal encounter.

Once a cetacean group was sighted, data were collected on time of sighting, position, angle of the animal(s) relative to the bow, angle of the bow of the boat relative to due north (using binoculars with compass), and the distance to the animals from the initial sighting. Distance was estimated based on the authors' previous experience, including on ship-based calibrated coastal surveys (first author).
These distance estimates were crudely corroborated by recording the boat's position when the animals were first sighted with the perceived precise position of the animals at the point of initial sighting once the group was approached (using a GPS). Additional data were collected on group size, group composition (adults or calves), and any distinctive behaviour or movements. Photo-identification was attempted with most groups sighted. A Canon EOS50 with 70-200 mm lens (f2.8) and 2x converter and a Canon EOS-500 with a Sigma $400 \mathrm{~mm}$ APO lens (f5.6) were used for photo-identification.

Interviews-Only informal interviews were undertaken during the course of field surveys. During the boat surveys, a number of fishers encountered were interviewed by Cambodian researchers on the boat. Although informal, a series of predetermined questions were asked, which focused on distribution of marine mammals sighted by fishers, seasonality of marine mammal sightings, and level of by-catch known to the interviewees. Discussions were also held with local residents of selected villages, particularly those in areas where marine mammals were thought to occur.

Recovery of Stranded Specimens-All marine mammal strandings reported through the Department of Fisheries or personal communication were investigated, and necropsies were performed whenever possible. The specimens were measured and photographed. Skeletal material were taken for identification purposes, and cranial morphology and skin samples were taken for genetic and contaminant analyses.

\section{Results}

Boat-Based Surveys-A total of seven boat-based surveys were conducted during the study period. In total, $203.75 \mathrm{~h}$ of survey covering $2,058 \mathrm{~km}$ of survey line were conducted. A total of eight cetacean species and 57 cetacean groups were sighted. Six of these constitute new country records for Cambodia: the false killer whale (Pseudorca crassidens), a long-beaked form of common dolphin (Delphinus capensis tropicalis), pantropical spotted dolphin (Stenella attenuata), dwarf spinner dolphin (S. longirostris roseiventris), Indo-Pacific bottlenose dolphin (Tursiops aduncus), and IndoPacific humpback dolphin. In addition, finless porpoise and Irrawaddy dolphin were also recorded. The presence of the offshore common bottlenose dolphin (T. truncatus) was unconfirmed, but highly likely, given the difference in body size, shorter rostrum, and lack of ventral spotting compared to the inshore Tursiops form also sighted during boat surveys. 


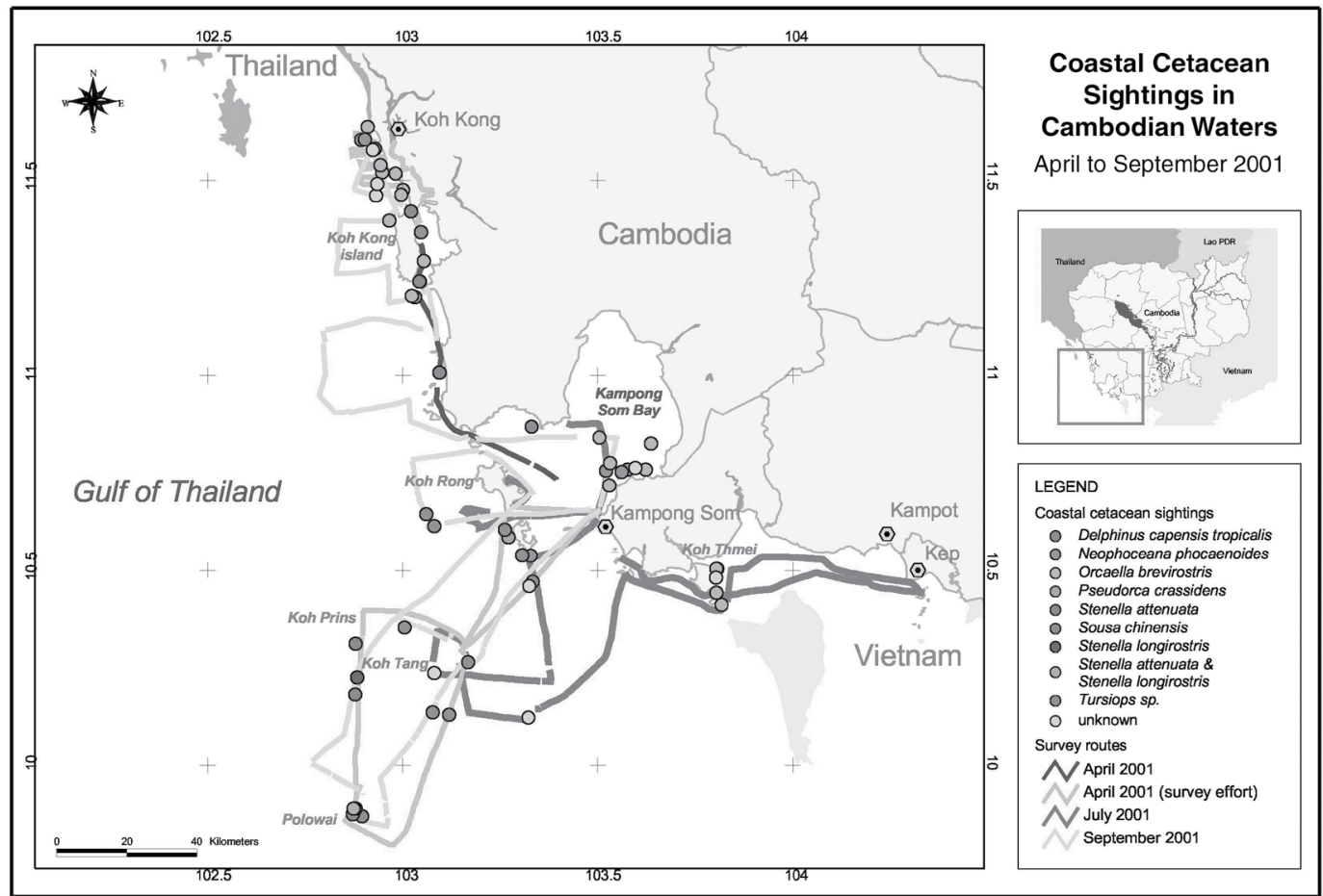

Figure 1. The survey lines travelled during coastal and offshore surveys and associated cetacean sightings from April to September 2001; survey lines for February-March are similar to those conducted in April 2001.

Table 1. Boat surveys undertaken in Cambodian waters

\begin{tabular}{|c|c|c|c|c|c|c|}
\hline Date & Location & \# days & $\begin{array}{l}\text { Total } \\
\text { hours }\end{array}$ & $\begin{array}{c}\text { Total } \\
\text { distance } \\
(\mathrm{km})\end{array}$ & \# groups & $\begin{array}{c}\text { Encounter rate } \\
\text { cetaceans/linear } \mathrm{km} / \\
\text { encounters/linear } \mathrm{km}\end{array}$ \\
\hline $\begin{array}{l}25 \text { February- } \\
1 \text { March } 2001\end{array}$ & $\begin{array}{l}\text { Ream National Park and } \\
\text { Kompong Som Bay }\end{array}$ & 5 & 17.8 & 184.0 & 7 & $0.15 / 0.03$ \\
\hline 23-26 March 2001 & $\begin{array}{l}\text { Kompong Som Bay north to } \\
\text { Koh Kong and offshore to } \\
\text { Koh Polou Wai }\end{array}$ & 4 & 22.5 & 211.7 & 6 & $0.52 / 0.03$ \\
\hline 20-29 April 2001 & $\begin{array}{l}\text { Kompong Som Bay north to } \\
\text { Koh Kong and offshore to } \\
\text { Koh Polou Wai }\end{array}$ & 10 & 723.5 & 67.0 & 23 & $0.38 / 0.04$ \\
\hline 22-25 June 2001 & Kampot and Kep & 4 & 3.4 & 36.2 & $0^{1}$ & $0.00 / 0.00$ \\
\hline 21-26 July 2001 & $\begin{array}{l}\text { Kompong Som Bay to Kep } \\
\text { and offshore to Koh Tang }\end{array}$ & 6 & 50.4 & 495.5 & 6 & $0.06 / 0.01$ \\
\hline $\begin{array}{l}\text { 7-9 September } \\
2001\end{array}$ & Koh Kong coastline & 3 & 14.2 & 111.3 & 7 & $0.41 / 0.06$ \\
\hline \multirow{2}{*}{$\begin{array}{l}\text { 11-14 September } \\
2001\end{array}$} & Koh Tang and Koh Polou Wai & 4 & 28.3 & 291.7 & 8 & $0.58 / 0.03$ \\
\hline & Total & 36 & 860.1 & $1,397.4$ & 57 & \\
\hline
\end{tabular}

${ }^{1}$ No marine mammals were sighted; however, the sighting conditions were very poor (Beaufort 3 or higher) 
Table 2. Summary of cetaceans sighted during boat surveys

\begin{tabular}{lccc}
\hline Coastal species & \# groups & Depth (min-max) & $\begin{array}{c}\text { Average group size } \pm \text { SD } \\
\text { (low-high estimates) }\end{array}$ \\
\hline Orcaella brevirostris & 20 & $8.0(1.6-16.7)$ & $7+4.32(1-15)$ \\
Tursiops sp. & 9 & $28.9(21.0-36.0)$ & $18+16.84(9-62)$ \\
Neophocaena phocaenoides & 8 & $17.0(1.5-34.0)$ & $4+2.80(1-10)$ \\
$\quad$ Sousa chinensis & 4 & $5.2(2.2-9.5)$ & $6+2.87(2-8)$ \\
\hline Offshore species & & & $45+9.45(38-56)$ \\
Unknown & 8 & $43.0(41.0-46.0)$ & $6(6-6)$ \\
Stenella attenuata & 3 & $41.5(41.0-42.0)$ & $12(8-16)$ \\
S. longirostris & 2 & $46.0(45.0-47.0)$ & $43(30-60)$ \\
Mixed group S. attenuata & 2 & & $45(33-61)$ \\
$\quad$ and $S$. longirostris & & 45.0 & 26.0 \\
$\quad$ Delphinus capensis tropicalis & 1 & & \\
Pseudorca crassidens & 1 & & \\
\hline
\end{tabular}

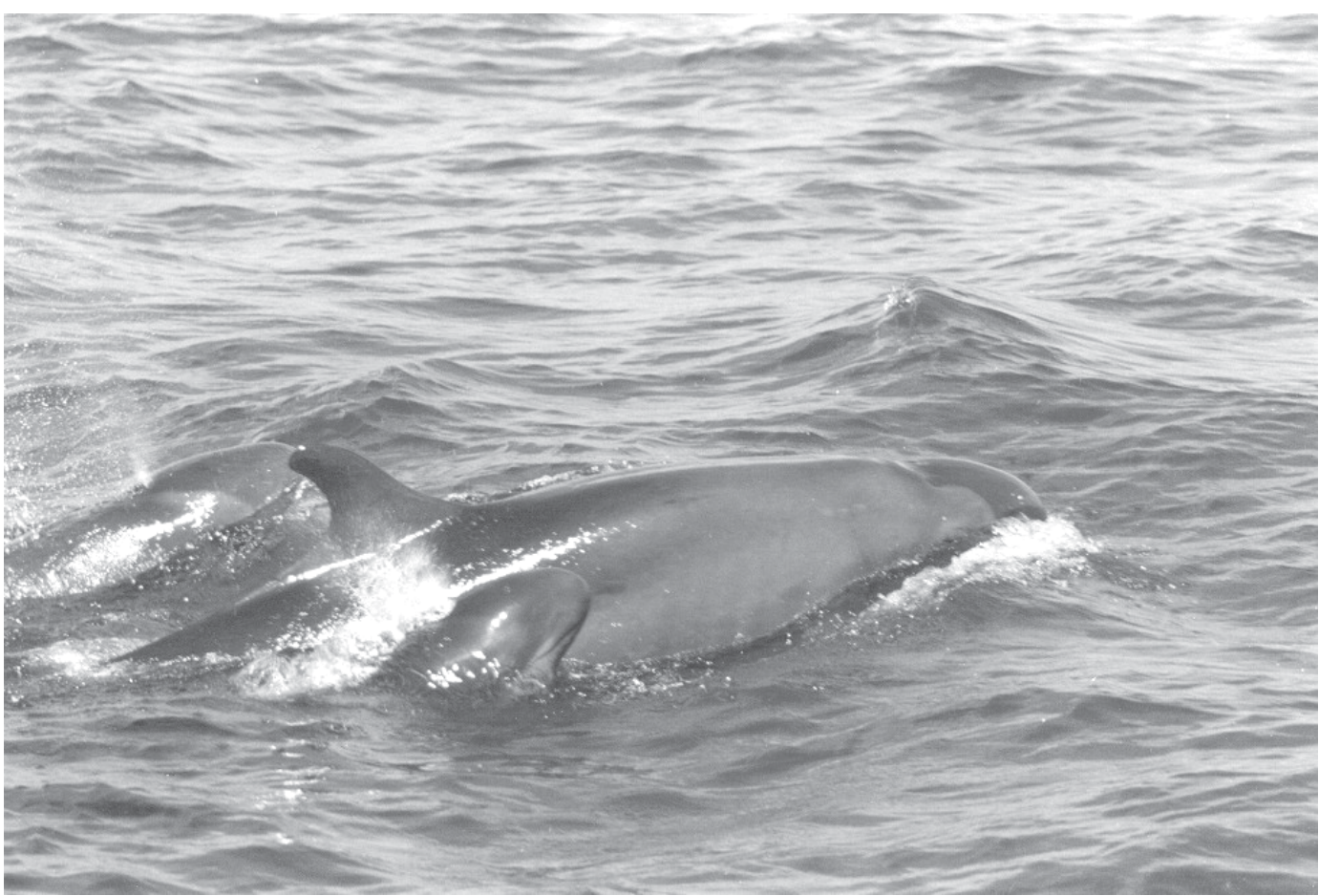

Figure 2. False killer whales sighted north of Koh Rong Samlaem Island; this group consisted of 45 (33 to 61) individuals and was the first record of this species for Cambodian waters.

Line-transect analyses were not possible as a result of the limited sightings obtained of each species. Based on the above surveys, however, the area with the highest encounter rate is the Koh Kong coastline from Koh Kong Island to the Thai border $(0.41$ cetaceans/linear $\mathrm{km}$ or 0.06 encounters/linear km surveyed). The offshore surveys (around Koh Tang and Koh Polou Wai archipelagos) show a higher number of cetaceans/linear $\mathrm{km}$ than coastal areas due to the larger group sizes of offshore cetaceans compared to coastal species.

The relative abundance in all other areas surveyed was similar; however, all surveys around Kampot and Kep were conducted in poor weather conditions (Beaufort 3 or greater). Therefore, the status of small cetaceans in the coastal areas of these areas remains rather poorly known. 


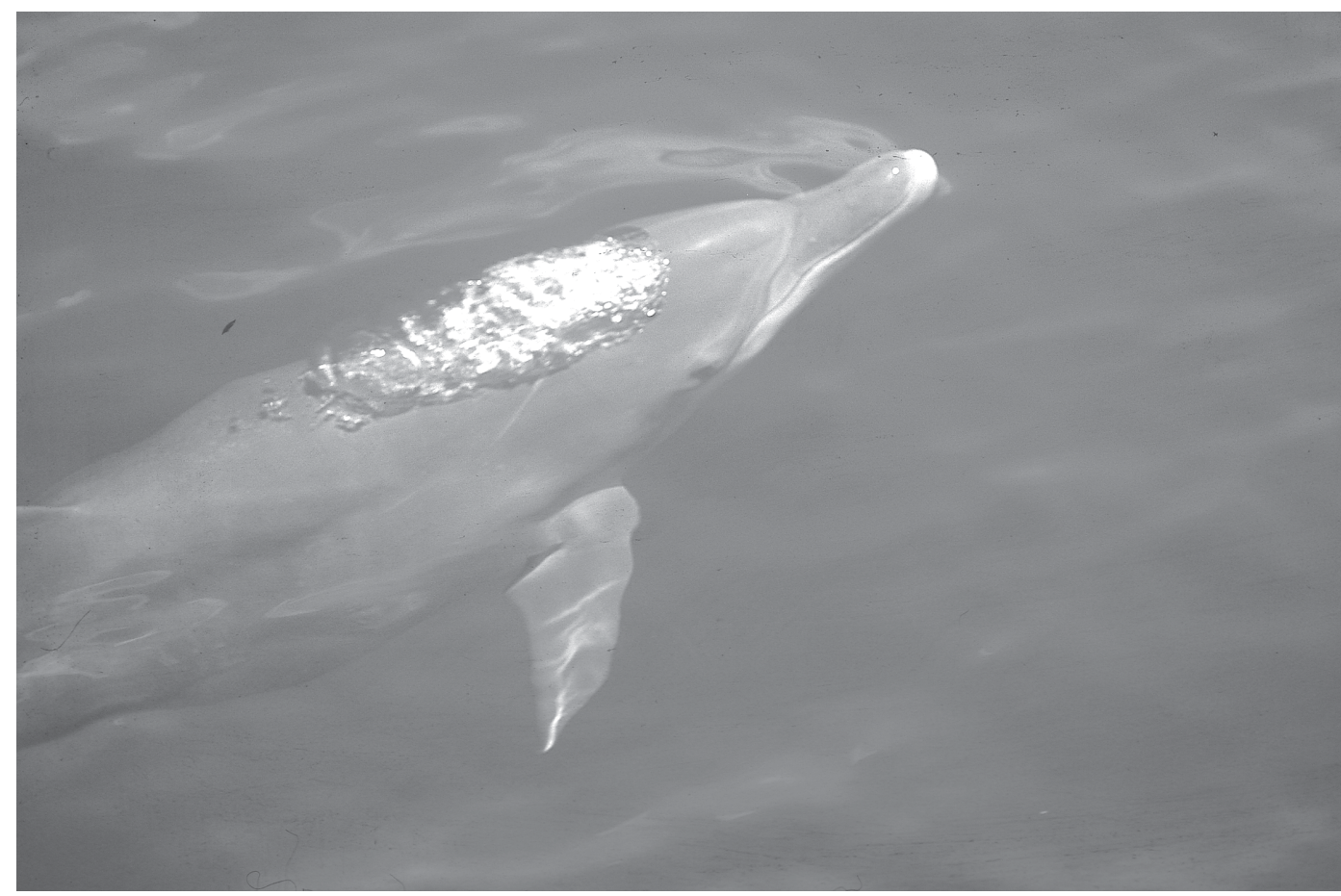

Figure 3. An Indo-Pacific bottlenose dolphin sighted just north of Kompong Som Bay; this species appeared distinct from the larger offshore form of bottlenose dolphin based on a longer rostrum, spotting on the ventral surface, and smaller group size.

Interview Surveys-As a direct result of interviews, a number of skeletal specimens were recovered, and potentially significant levels of by-catch became apparent-particularly with certain net types and fishing techniques. Most interviewees were either experienced fishers or local traders of various harvestable marine resources. All were familiar with marine mammals and reported seeing cetacean groups with varying regularity. A series of laminated illustrations/photographs was shown to each interviewee to judge their reliability at identifying the species that occur/are likely to occur in Cambodian waters. Responses indicated that at least some interviewees were not familiar with even the most likely species to be found in their area (e.g., Irrawaddy dolphin), although this may be due to their being unaccustomed to relating photographs/illustrations to what they observe in reality.

The range of fishing gear and techniques employed in Cambodian waters was quite diverse. Strong nylon nets were used in the Spanish Mackerel fishery. Monofilament line gillnets of varying mesh sizes were used in crab, prawn, and shrimp fisheries (and generally left out for 4 to $5 \mathrm{~h}$ before hauling in again), which were particularly prevalent in Kompong Som Bay and adjacent waters, as are squid traps. The latter apparently present no potential danger to marine mammals. The lengths of net used by the different fishers apparently varied considerably according to personal wealth, etc., but it was reported that most nets were a minimum of 100-m long and frequently up to $1 \mathrm{~km}$ of nets were set by one boat. Many crab and shrimp/prawn nets were apparently watched by their owners for the duration of the fishing period (for fear that they may become entangled in trawls, etc.); however, some types of monofilament gillnets were set overnight (set-nets), and in some places for up to two days, without being watched over by their owners. These reportedly presented the greatest threat to dolphins. Small trawls were particularly prevalent in the Kompong Som Bay area. Each trawl session usually lasted 30 to $40 \mathrm{~min}$ over a period of 3 to 4 h. Purse-seine nets were also reported to be used quite widely.

All interviewees were familiar with the fact that dolphins were at least occasionally by-caught, particularly in monofilament line gillnets (set for crab and prawn) and the stronger nylon Spanish Mackerel nets. Several recent examples were quoted (two of which led to the acquisition of the animal in question's skull). Although the following figures quoted should be treated with caution, 
information suggested that on average at least one dolphin was caught in fishing nets in the Kompong Som Bay area every 1 to 3 mo, and perhaps up to $50 / y$, according to one informant.

Discussions with fish sellers indicated that Thai traders were keen to purchase dolphin meat if the opportunity arose. Given the apparently quite strictly observed taboos concerning catching, killing, and consuming cetaceans in Khmer culture, however, there seemed to be few people who were willing to take part in such activities (although at least one interviewee divulged details of a probable Indo-Pacific humpback dolphin that had died in his Spanish mackerel net, the meat of which he sold to Thai traders). All interviewees held a very strong belief that it was very unlucky to catch dolphins in their fishing nets and that they would release any dolphins caught if they were still alive. The dugong, however, is not held in the same high cultural regard and has reportedly been caught and traded frequently, particularly in the Kep/Kampot area.

Resulting from the interview surveys, several main points became apparent:

1. Local fishers have very little awareness regarding marine mammals. Only the IndoPacific humpback dolphin has a specific Khmer name (Phsout Kleit). All other species are categorized under one Khmer name (Phsout or "dolphin").

2. A small percentage of local fishers and the majority of new immigrants to coastal areas continue to confuse dolphins with fish.

3. There are a number of fishing nets used throughout coastal waters which accidentally catch marine mammals. The main nets responsible for by-catch are Spanish Mackeral, shrimp, crab, and baka nets.

4. Although cetaceans are held in very high cultural regard with local Khmer, to the point where it is considered unlucky to catch a cetacean while fishing, the Cambodian "Cham" (Muslim) and Vietnamese apparently do not hold such strong cultural beliefs and will often eat cetacean meat and will not release cetaceans alive if caught in nets.

5. The main beliefs concerning dolphins in Cambodia are that (1) it is unlucky to catch a dolphin while fishing (2) dolphins will help people at sea if they are in trouble (3) there will be a storm if dolphins go into tributaries, and (4) placing the bones of marine mammals in front of houses will protect the inhabitants from bad spirits.

6. All fishers believed it was very "lucky" to catch a dugong due to the high price paid for the bones and tusks for medicinal purposes and the meat for human consumption. Although dugongs are now rarely reported from Koh Kong Province, a number of reports and fresh carcasses are reported from Kampot and Kep.

7. Most fishers encouraged the conservation of marine mammals in Cambodian coastal waters. A large majority of fishers were agreeable to the development of national laws concerning marine mammal conservation and protection; however, fewer fishers were in support of regulations which would stop them from fishing in marine mammal conservation areas.

Recovery of Stranded Specimens-During the course of the study period, a number of dolphin carcasses and specimens were recovered based on reports by local residents and Department of Fisheries officials. A short-finned pilot whale (Globicephala macrorhynchus) carcass was recovered on 9 February 2001 after it had stranded alive on a Kep beach and then died a few days later. This was the first reported occurrence of a shortfinned pilot whale in Cambodian waters.

The awareness of many local people towards cetaceans along the coastal area is generally low, and many new immigrants from inland provinces continued to confuse dolphins with fish. As an example, this confusion resulted in the butchering of five Irrawaddy dolphins, which had been stranded by low water near Sre Ambel, Kompong Som Bay, in June 2002. All of the dolphins were killed for food because the local people (who were apparently not fishers) confused the dolphins with large fish. The skull and skin were retrieved from just one individual. The body parts of the other four dolphins were not located.

There have been occasional reports of similar occasions in which dolphins are killed either because local people have been afraid of them or because they have been confused with big fish.

\section{Discussion}

\section{Diversity and Abundance of Marine Mammals in Cambodian Waters}

Based on studies from neighbouring countries, it is highly likely that further cetacean species remain unrecorded for Cambodian coastal waters. Based on the boat surveys and interviews, early indications are that Cambodian waters support regionally (and perhaps globally) significant marine mammal populations. Cetacean encounter rates from boatbased surveys are substantially higher than those recorded recently in adjacent Vietnamese waters, with no known encounter rates available from Thai coastal waters for comparison (Smith et al., 1995, 1997; Mahakunlayanakul, 1996). Particularly 
encouraging numbers of the three shallow, inshore water specialists have been recorded, namely Irrawaddy dolphin, Indo-Pacific humpback dolphin, and finless porpoise. A surprisingly high species diversity of more oceanic species has also been recorded during boat-based surveys, including several new country records; however, the shallow seas and gentle seabed gradient, lacking any marked "shelving" or other prominent underwater features, may constitute a limiting factor to marine mammal species diversity (for more oceanic species).

There is currently insufficient data from which to assess the relative abundance of the more oceanic species recorded (Indo-Pacific common dolphin, pantropical spotted dolphin, dwarf spinner dolphin, bottlenose dolphin, and the "blackfish"false killer whale and short-finned pilot whale). Even so, given that the dwarf spinner dolphin is only known from the Gulf of Thailand (perhaps extending south to northern Indonesia) and the Indo-Pacific common dolphin record is only the second for the Gulf of Thailand, Cambodia currently appears to support an important diversity of offshore cetaceans typical of a shallow water, tropical Southeast Asian cetacean community.

Although considerably more data will be required before any meaningful abundance estimates can be made, it is already clear that there are certain key areas or "hotspots" for marine mammals in Cambodian waters. Marine mammal hotspots identified thus far are the following:

- Koh Kong Bayand the adjacentwaters around Koh Kong Island, stretching north up the coast to the Thai border. This area appears to be particularly important for both Irrawaddy dolphin and Indo-Pacific humpback dolphin (with eight and four encounters recorded, respectively, in just ca $5 \mathrm{~h}$ of effort, certainly

Table 3. Checklist of all confirmed marine mammal species found in Malaysia (Ma), Brunei (Br), Singapore (Si), Thailand (Th), Myanmar (My), Cambodia (Ca), Vietnam (Vi), and the Philippines (Ph) (Jaaman et al., 2000; Perrin et al., 2005)

\begin{tabular}{|c|c|c|c|c|c|c|c|c|c|}
\hline Species & Ma & $\mathrm{Br}$ & $\mathrm{Si}$ & $\mathrm{Th}$ & My & $\mathrm{Ca}$ & $\mathrm{Vi}$ & In & $\mathrm{Ph}$ \\
\hline Humpback whale (Megaptera novaeangliae) & & & & & & & $\mathrm{X}$ & $\mathrm{X}$ & $\mathrm{X}$ \\
\hline \multicolumn{10}{|l|}{ Minke whale (Balaneoptera acutorostrata) } \\
\hline Bryde's whale (Balaenoptera edeni) & $\mathrm{X}$ & $\mathrm{X}$ & & & $\mathrm{X}$ & & & $\mathrm{X}$ & $\mathrm{X}$ \\
\hline Sei whale (Balaenoptera borealis) & & & & & & & & $\mathrm{X}$ & \\
\hline Fin whale (Balaenoptera physalus) & $\mathrm{X}$ & & & & & & & $\mathrm{X}$ & $\mathrm{X}$ \\
\hline Blue whale (Balaenoptera musculus) & & & & & & & $\mathrm{X}$ & & \\
\hline Sperm whale (Physeter macrocephalus) & $\mathrm{X}$ & & & & & & & $\mathrm{X}$ & $\mathrm{X}$ \\
\hline Pygmy Sperm whale (Kogia breviceps) & $\mathrm{X}$ & & & $\mathrm{X}$ & & & $\mathrm{X}$ & $\mathrm{X}$ & $\mathrm{X}$ \\
\hline Dwarf Sperm whale (Kogia sima) & & $\mathrm{X}$ & & & & & $\mathrm{X}$ & $\mathrm{X}$ & $\mathrm{X}$ \\
\hline Cuvier's Beaked whale (Ziphius cavirostris) & $\mathrm{X}$ & & & & & & & $\mathrm{X}$ & $\mathrm{X}$ \\
\hline Ginko-toothed beaked whale (Mesoplodon ginkgodens) & & & $\mathrm{X}$ & & & & & & \\
\hline Blainville beaked whale (Mesoplodon densirostris) & & & & & & & & $\mathrm{X}$ & \\
\hline Rough toothed dolphin (Steno bredanensis) & $\mathrm{X}$ & $\mathrm{X}$ & & $\mathrm{X}$ & & & $\mathrm{X}$ & $\mathrm{X}$ & $\mathrm{X}$ \\
\hline Indo-pacific humpback dolphin (Sousa chinensis) & $\mathrm{X}$ & $\mathrm{X}$ & $\mathrm{X}$ & $\mathrm{X}$ & $\mathrm{X}$ & $\mathrm{X}$ & $\mathrm{X}$ & $\mathrm{X}$ & \\
\hline Common bottlenose dolphin (Tursiops truncatus) & $\mathrm{X}$ & $\mathrm{X}$ & & & & & & & $\mathrm{X}$ \\
\hline Indo-pacific bottlenose dolphin (Tursiops aduncus) & $\mathrm{X}$ & $\mathrm{X}$ & $\mathrm{X}$ & $\mathrm{X}$ & $\mathrm{X}$ & $\mathrm{X}$ & $\mathrm{X}$ & $\mathrm{X}$ & $\mathrm{X}$ \\
\hline Pantropical spotted dolphin (Stenella attenuata) & $\mathrm{X}$ & & & $\mathrm{X}$ & $\mathrm{X}$ & $\mathrm{X}$ & $\mathrm{X}$ & $\mathrm{X}$ & $\mathrm{X}$ \\
\hline Spinner dolphin (Stenella longirostris sp.) & $\mathrm{X}$ & $\mathrm{X}$ & & $\mathrm{X}$ & $\mathrm{X}$ & $\mathrm{X}$ & $\mathrm{X}$ & $\mathrm{X}$ & $\mathrm{X}$ \\
\hline Striped dolphin (Stenella coeruloalba) & & & & $\mathrm{X}$ & & & $\mathrm{X}$ & $\mathrm{X}$ & $\mathrm{X}$ \\
\hline Common dolphin (Delphinus sp.) & $\mathrm{X}$ & & $\mathrm{X}$ & $\mathrm{X}$ & $\mathrm{X}$ & $\mathrm{X}$ & $\mathrm{X}$ & $\mathrm{X}$ & \\
\hline Frasers dolphin (Lagenodelphis hosei) & $\mathrm{X}$ & & & & & & & $\mathrm{X}$ & $\mathrm{X}$ \\
\hline Risso's dolphin (Grampus griseus) & $\mathrm{X}$ & $\mathrm{X}$ & & & $\mathrm{X}$ & & $\mathrm{X}$ & $\mathrm{X}$ & $\mathrm{X}$ \\
\hline Melon headed whale (Peponocephala electra) & $\mathrm{X}$ & & & $\mathrm{X}$ & & & $\mathrm{X}$ & $\mathrm{X}$ & $\mathrm{X}$ \\
\hline Pygmy killer whale (Feresa attenuata) & $\mathrm{X}$ & & & $\mathrm{X}$ & & & $\mathrm{X}$ & $\mathrm{X}$ & $\mathrm{X}$ \\
\hline False killer whale (Pseudorca crassidens) & $\mathrm{X}$ & & & $\mathrm{X}$ & & $\mathrm{X}$ & $\mathrm{X}$ & $\mathrm{X}$ & $\mathrm{X}$ \\
\hline Killer whale (Orcinus orca) & $\mathrm{X}$ & & & & & & & $\mathrm{X}$ & $\mathrm{X}$ \\
\hline Short-finned pilot whale (Globicephala macrorhynchus) & $\mathrm{X}$ & $\mathrm{X}$ & & $\mathrm{X}$ & & $\mathrm{X}$ & $\mathrm{X}$ & $\mathrm{X}$ & $\mathrm{X}$ \\
\hline Irrawaddy dolphin (Orcaella brevirostris) & $\mathrm{X}$ & $\mathrm{X}$ & & $\mathrm{X}$ & $\mathrm{X}$ & $\mathrm{X}$ & $\mathrm{X}$ & $\mathrm{X}$ & $\mathrm{X}$ \\
\hline Finless porpoise (Neophocaena phocaenoides) & $\mathrm{X}$ & $\mathrm{X}$ & $\mathrm{X}$ & $\mathrm{X}$ & & $\mathrm{X}$ & $\mathrm{X}$ & $\mathrm{X}$ & $\mathrm{X}$ \\
\hline Dugong (Dugong dugon) & $\mathrm{X}$ & $\mathrm{X}$ & $\mathrm{X}$ & $\mathrm{X}$ & $\mathrm{X}$ & $\mathrm{X}$ & $\mathrm{X}$ & $\mathrm{X}$ & $\mathrm{X}$ \\
\hline
\end{tabular}


the highest sighting rates of these two species of any area surveyed to date). The area may also be important for finless porpoise.

- Kompong Som Bay. Although no encounters were recorded in the mouth of the bay, the shallow waters from ca $15 \mathrm{~km}$ north of Kompong Som, following the coast north, appear to be important for both Irrawaddy dolphin and finless porpoise. The coastal area around Tmor Sor village appears to be particularly important for Indo-Pacific humpback dolphins, which local fishers convincingly described as occurring there during initial interview surveys.

- $\quad$ Ream National Park and the adjacent waters around Koh Thmei and Koh Ses. Irrawaddy dolphins inhabit this area.

- The offshore waters of the Gulf of Thailand, west and south of Koh Rong and Koh Rong Samlaem, encompassing the Koh Tang and Koh Polou Wai island groups. All survey records of the more oceanic species stem from this area.

- $\quad$ The waters around Kep and Kampot, abutting the Vietnamese border. Based on interview surveys, these waters are potentially important for dugong and at least formerly appear to have supported a substantial population of the species. The dugong has also been convincingly reported as occurring around Koh Rong and Koh Rong Samlaem, although it probably only persists in that area occasionally and in very low numbers.

Threats to Marine Mammals in Cambodian Waters By-Catch in Fisheries-A number of threats have become evident, both from direct observation during surveys and through interviews, which may be potentially impacting coastal populations within (and outside) Cambodian waters. By-catch in fisheries appears to be the most immediate concern. Fishers quite frequently report catches of dolphins in their nets (particularly in Spanish Mackerel fishing nets). Although the dolphins are being caught accidentally, they are usually dead when the fishers reach them. This primarily appears to be due to the fishing method employed - the use of many gillnets - which are sometimes left unattended by fishers for periods of 1 to $2 \mathrm{~d}$ before being recovered. As in most countries where gillnets and cetaceans are found in close proximity, by-catch is potentially a major problem.

Habitat Degradation and Overfishing-Habitat degradation and overfishing are immediately evident throughout both the inshore and more oceanic offshore waters of Cambodia. As with other parts of Southeast Asia, fisheries pressure is significant in Cambodian coastal waters. Fishing methods have changed greatly over the last $20 \mathrm{y}$. Modern methods have increased efficiency of catch and are thought to have contributed to a decline in catches. Many fishers use prohibited gear, such as motorised push nets that destroy the substratum (seagrass and soft bottoms), and dynamite and trawl nets in shallow water. Fishing is prohibited in water $<20 \mathrm{~m}$ deep by law, but nearly all fishing in Cambodia, including trawling, is conducted close to the shore in water as shallow as 1 to $2 \mathrm{~m}$ (Nelson, 1999).

Large trawlers (fishing both single and pairtrawls), registered and based in Thailand (but evidently allowed to trawl in Cambodian waters), essentially "scour" the entire water column and benthic environment when actively trawling offshore. The catch is nonselective, and much of the seabed is likely to be destroyed during each trawl. In addition to the larger trawls, a large number of small-scale Cambodian trawls actively fish more inshore waters every night in the same manner. Each evening, in excess of 200 of these small trawling vessels can be counted departing Kompong Som Harbour, returning again at dawn the following day.

Seagrass Destruction-According to reports by district fisheries officials in Nelson (1999), stands of seagrass at least formerly occurred in Kompong Som Bay. High intensity trawling and push netting have reportedly destroyed most of these beds, however. Small seagrass beds have been found around Koh Rong and Koh Rong Samlaem Islands, southwest and west of Kompong Som.

Nelson (1999) reports that seagrasses are under severe threat from destructive fishing practices and potentially from declines in water quality associated with agricultural use of fertilisers and pesticides. Trawling and fishing using weighted bottom nets destroy seagrasses by ripping them out of the bottom substrate. Reports from socioeconomic surveys and workshops with the officers from the Department of Fisheries indicate that fisheries catches are declining in seagrass areas, and locals and government officials alike are very concerned about trawling in seagrass beds (Nelson, 1999). At present, there is some very intensive trawling and push netting occurring around Kep, which is severely threatening one of the last likely strongholds for dugongs in Cambodia.

Direct Catch for Dugongs-Recent interview surveys in the Kampot and Kep regions indicate that although there is no direct catch for cetaceans (due to superstitions and folklore), dugongs are directly persecuted and of great monetary value. The meat and internal organs are consumed $(\$ 1.10 \mathrm{USD} / \mathrm{kg})$, and the bones and teeth are used for traditional medicinal purposes, with one tusk fetching up to $\$ 100$ USD. It was reported by 
the Kep Fisheries Office, Kep Municipality, that many dugongs reported stranded are not recovered because local people take their bones to use as medicine against fevers and to protect their livestock against ills. Due to the high monetary and traditional use value attached to a dugong, it is almost certainly the most highly threatened marine mammal in Cambodian waters.

Live-Capture for Aquaria Display-Live-capture for display is an ever-increasing problem in Asia. It has been known for some years that cetaceans have been removed from Cambodian waters near the Thai border to stock two oceanariums in Thailand: Safari World in Munburi, Bangkok, and Oasis Sea World in Chantaburi Province (Stacey \& Leatherwood, 1997). Eight Irrawaddy dolphins were caught during net operations in 1994 in the coastal waters of Cambodia and transported to Safari World (Perrin et al., 1996). Two dolphins, presumably from this collection, were then transported to Marine World in Japan. All individuals at these two facilities have since died. Oasis Sea World currently holds numerous Irrawaddy dolphins and Indo-Pacific humpback dolphins, although many are known to have died at this facility and it is probable that a large number were taken directly from Cambodian coastal waters.

In January 2002, Koh Kong International Resort on the Cambodian/Thai border captured significant numbers of both Irrawaddy dolphins and Indo-Pacific humpback dolphins for display at their resort. Although unconfirmed due to the difficulty of obtaining information from the casino, it is believed that all of these dolphins have since died. These captures have potentially caused a significant impact on the status of the populationsparticularly the apparently localised Indo-Pacific humpback dolphin population.

\section{Legislation and Development of Marine Protected Areas}

At present, there is no official legislation in Cambodia protecting marine mammals from direct or incidental takes, capture, or harassment. There are currently minimal coastal zone management laws concerning protected areas, fishing, industrial development, land use, and waste management, and in many cases, existing laws are weak and under revision. Even for the fisheries legislation that does exist, there is very little enforcement of these laws. Limited resources within Cambodia have resulted in lack of funds for patrols and arrests. As an example, fisheries officers have the legal power to arrest illegal fishers and mangrove cutters, but no arrests are made due to insufficient operating funds and slow boats (Nelson, 1999). The Cambodian Fisheries Law is now under extensive revision, however, and will apparently provide for stricter legal protection of Cambodian marine mammals in the future.

It has been proposed that Marine Protected Areas (MPAs) be established in Cambodian waters by the Cambodian Department of Fisheries. If developed appropriately, these MPA sites may assist with the conservation and management of marine mammal populations, particularly coastal species such as Irrawaddy and Indo-pacific humpback dolphins. Of particular interest would be the potential establishment of an MPA in the Kampot and Kep regions, specifically dedicated to conserve and protect the dugong.

\section{Future Research, Conservation, and Management} Based on research conducted in 2001, it is suggested that public awareness and education programs should be an immediate priority throughout Cambodian coastal communities, particularly targeting areas that have been identified as hotspots of conservation importance to the coastal marine mammal species. The high cultural protection afforded to cetaceans assists considerably with conservation strategies; however, many inland provincial immigrants to coastal regions have been known to mistake dolphins with fish, which results in unnecessary deaths.

Preliminary hotspots for coastal species (including dugong) have been identified in Cambodian coastal waters. Further intensive surveys should be conducted to assist with developing core areas of habitat usage, which should be proposed for incorporation into marine conservation/protection areas and future management strategies as appropriate.

Specific research into threats (e.g., by-catch) and their impact on marine mammals is urgently needed. The identification of key threats and the development of potential management solutions of these threats (such as through existing and developing legislation) is required. In addition, increased collaboration with Thai and Vietnamese researchers and international ministerial cooperation between governments will be essential in order to effectively address transboundary threats, particularly overfishing.

Importantly, if the dugong population is to survive in Cambodian waters, it will take significant resources (both financial and logistical) to accomplish conservation strategies. The identification and protection of important seagrass beds and the establishment of a patrolled MPA may be the only realistic measure that could be taken to prevent direct catch in specific areas-and to ensure dugongs are released if by-caught in fishing gears. Cooperation with Vietnamese researchers and authorities would be essential as the small remaining dugong population in this region is 
extremely likely to be moving between Vietnam and Cambodia.

These initial results indicate that the current status of marine mammals in the coastal waters of Cambodia is encouraging, both in terms of species diversity (particularly among the typically more oceanic species, for which the waters of the Koh Tang and Koh Polou Wai archipelagos seem to be a key area) and abundance (especially the three inshore water specialists-Irrawaddy dolphin, Indo-Pacific humpback dolphin, and finless porpoise-for which Koh Kong Bay and its adjacent waters, Kompong Som Bay, and Ream National Park appear to be of key importance). Cambodian waters appear to support regionally, if not globally, significant populations of several of these species.

Studies to date have provided important baseline knowledge regarding the status, distribution, and important areas for marine mammals in Cambodia. It is now essential that conservation and management strategies are developed and implemented. Public education and awareness and community-based management programs, as well as stricter laws, regulations, and adequate enforcement, will be essential to conserving the remaining marine mammal populations and ensuring their survival in Cambodian waters.

\section{Acknowledgments}

Funding for this research was provided by Ocean Park Conservation Foundation, Hong Kong; the PADI Foundation; and the Wildlife Conservation Society - Research Fellowship Fund. In Phnom Penh, we would like to thank Excellency Nao Thouk, Director of the Department of Fisheries, and Mr. Ing Try, Deputy Director of the Department of Fisheries, for their invaluable assistance with permissions and advice on project execution. In addition, Mr. Colin Poole, WCS Cambodia Program manager, has provided invaluable logistical support, management, and helpful discussion concerning a number of issues. We are very thankful to Phay Somany, Leng Samath, and Pich SeriWat from the Cambodian Department of Fisheries for their invaluable assistance during all boat surveys, interviews, and report writing. Many thanks also to Tom Jefferson for his support, assistance, and helpful suggestions. We are especially grateful to Isabelle Roubeix, and Eric and Stephane Rieu for the use of their boat to conduct both inshore and offshore surveys, and for their skills, cooperation, and hard work during numerous long days of navigation, and their friendship and hospitality, which contributed immeasurably to the smooth running of all the line-transect surveys.

Federico Riet (James Cook University), Nhem Vanna (Aquaculture Division, Fisheries Office of Kompong Som), and Mr. Riet (Department of Fisheries, Koh Kong) all took part as observers in at least one boat-based survey. Thanks to Va Long Dy and Chea Mong (Chamkar Dong University) for undertaking the interview surveys and participating in boat surveys. Thanks also to all Fishery Office Chiefs, who assisted with research and logistics in each of the Provinces: Mr. Nov Rattana (Chief of Agriculture and Fisheries Office, Sihanouk Ville), Mr. Doug Sam Ath (Deputy Chief of Fishery Office, Sihanouk Ville), Mr. Song Lun (Chief of Fishery Office, Kampot Province), Mr. Tit Sara (Chief of Fishery Office, Kep Municipality), Mr. Nay Ol (Chief of Fishery Office, Koh Kong Province), and Mr. Pen Vann Rit (Deputy Chief of Fishery Office, Koh Kong Province). We are also grateful to the various local boat drivers who took the team out on surveys, and the interviewees who took time to discuss numerous issues at some length.

IB would like to thank Helene Marsh and the late Peter Arnold for their valuable advice and encouragement.

\section{Literature Cited}

Andersen, M., \& Kinze, C. C. (1999). Report of the Workshop and Seminar on Marine Mammals and Sea Turtles of Cambodian, Thai and Vietnamese Waters. Nha Trang Institute of Oceanography, 8-13 February 1999 (not viewed, but cited in Anderson \& Kinze, 2000).

Andersen, M., \& Kinze, C. C. (2000). Review and new records of the marine mammals and sea turtles of Indochinese waters. Natural History Bulletin of the Siam Society, 48, 177-184.

Aragones, L. V., Jefferson, T. A., \& Marsh, H. (1997). Marine mammal survey techniques applicable in developing countries. Asian Marine Biology, 14, 15-39.

Beasley, I. L. (2007). Conservation of the Irrawaddy dolphin population in the Mekong River: Biological and social considerations influencing management. Ph.D. thesis, School of Earth and Environmental Science, James Cook University, Townsville, Queensland, Australia. 457 pp.

Beasley, I. L., Chooruk, S., \& Piwpong, N. (2002). The status of Irrawaddy dolphin, Orcaella brevirostris, in Songkhla Lake, southern Thailand. Raffles Bulletin of Zoology (Supplement), 10, 75-83.

Bonhote, J. L. (1903). Anthropological and zoological results of an expedition to Perak and the Siamese Malay States, 1901-1902: Report on the mammals. Fasciculi Malayensis Zoology, 1, 1-45.

Buckland, S. T., Anderson, D. R., Burnham, K. P., \& Laake, J. L. (1993). Distance sampling: Estimating abundance of biological populations. London: Chapman and Hall. (Reprinted in 1999 by RUWPA, University of St. Andrews, Scotland). 
Chantrapornsyl, S., Adulyanukosol, K., \& Kittiwathanawong, K. (1996). Records of cetaceans in Thailand. Phuket Marine Biology Centre Research Bulletin, 61, 39-63.

Chantrapornsyl, S., Adulyanukosol, K., \& Kittiwattanawong, K. (1999). Stranded cetaceans from Thailand. IBI Reports, 9, 55-72.

Cox, N. (2000). Preliminary status report for the dugong Dugong dugon in Con Dao National Park - Vietnam. Unpublished report.

Ethirmannasingan, S. (1996). Preliminary survey for Cambodian seagrass resources. Unpublished report to Wetlands International, Cambodia-Mekong Programme. 5 pp.

Gruvel, A. (1925). L'Indochine, ses richesses marines et fluviales. Paris: Society of Geological Maritime College. (Not viewed).

Hines, E. (2005). Dugong (Dugong dugon) abundance along the Andaman coast of Thailand. Marine Mammal Science, 21(3), 536-549.

Ho, D., \& Nghi, B. Q. (1999). Review on the status of marine mammals in Vietnamese waters. Paper presented at the Workshop and Seminar on Marine Mammals and Sea Turtles. Nha Trang Institute of Oceanography, 8-13 February 1999. 13 pp. (Not viewed, but cited in Anderson \& Kinze, 2000).

Jaaman, S. A., Tangon, E., Isnain, I., Ali, S. A., \& Anyi, Y. U. (2000). First records of the false killer whale (Pseudorca crassidens) and Cuvier's beaked whales (Ziphius cavirostris) from Sabah, Malaysia. Malayan Nature Journal, 54(4), 319-322.

Jefferson, T. A., Leatherwood, S., \& Webber, M. A. (1993). FAO species identification guide: Marine mammals of the world. Rome: FAO.

Krempf. (1924-1925). Campagnes de Lanessan Rapp Fonct. Hanoi: Institute Oceanography Indochine. 255 pp (Not viewed).

Lekagul, B., \& McNeely, J. A. (1977). Mammals of Thailand. Bangkok: Association for the Conservation of Wildlife. 758 pp.

Lloze, R. (1973). Contribution a l'etude anatomique histologique et biologique de l'Orcaella brevirostris (Gray, 1866) (Cetacea, Delphinidae) du Mekong. Ph.D. dissertation, L'Universite Paul Sabatier de Toulouse, France. 598 pp.

Mahakunlayanakul, S. (1996). Species distribution and status of dolphins in the Inner Gulf of Thailand. Master's thesis, Department of Marine Science, Chulalongkorn University. 129 pp.

Marsh, H., Penrose, H., Eros, C., \& Hugues, J. (2002). Dugong: Status report and action plans for countries and territories (UNEP/DEWA Report). $162 \mathrm{pp}$.

Nay, O. (1998). Fisheries in Koh Kong Province (Unpublished report). Koh Kong, Cambodia: Fisheries Office, Cambodian Department of Fisheries.

Nelson, V. (1999). The coastal zone of Cambodia-Current status and threats: Volumes I and II. Unpublished report for the Ministry of Environment and DANIDA.
Perrin, W. F., Dolar, M. L. L., \& Alava, M. N. R. (1996). Report of the Workshop on the Biology and Conservation of Small Cetaceans and Dugongs of Southeast Asia. Dumaguete: United Nations Environment Programme.

Perrin, W. F., Leatherwood, S., \& Dolar, M. L. L. (1995). The status of marine mammal research in Southeast Asia (UNEP/SEA95/BP6, IBI Reports No. 5). 16 pp.

Perrin, W. F., Reeves, R. R., Dolar, M. M. L., Jefferson, T. A., Marsh, H., Wang, J. Y., et al. (2005). Report of the Second Workshop on the Biology and Conservation of Small Cetaceans and Dugongs of Southeast Asia (CMS Technical Series Publication No. 9). UNEP/CMS Secretariat. $161 \mathrm{pp}$.

Pilleri, G., \& Gihr, M. (1974). Contribution to the knowledge of the cetaceans of Southwest and Monsoon Asia (Persian Gulf, Indus Delta, Malabar, Andaman Sea and Gulf of Siam). Investigations on Cetacea, 5, 95-149.

Smith, B. (1996). Whale worship in Vietnam. Wiltshire, UK: Whale and Dolphin Conservation Society.

Smith, B., Jefferson, T. A., Leatherwood, S., Ho, D. T., Thuoc, C. V., \& Quang, L. E. (1997). Investigations of marine mammals in Vietnam. Asian Marine Biology, 14, 145-172.

Smith, B., Jefferson, T. A., Ho, D. T., Leatherwood, S., Thuoc, C. V., Andersen, M., et al. (1995). Marine mammals of Vietnam: A preliminary checklist. Collection of Marine Research Works, 6, 147-176.

Stacey, P. J., \& Leatherwood, S. (1997). The Irrawaddy dolphin Orcaella brevirostris: A summary of current knowledge and recommendations for conservation action. Asian Marine Biology, 14, 195-214.

Suvatti, C. (1950). Fauna of Thailand. Bangkok: Applied Scientific Research Corporation of Thailand, Department of Fisheries.

Tana, T. S., Chea, Y., \& Chamnan, C. (1995). Review of the oceanography, natural resources and fisheries of the coastal zone of Cambodia. Unpublished report of the project for the Management of Freshwater Capture Fisheries of Cambodia, Ministry of Agriculture, Forestry and Fisheries. 
Reproduced with permission of the copyright owner. Further reproduction prohibited without permission. 